\title{
Diversity for Peace: India’s Cultural Spirituality
}

\author{
Indira Y. Junghare \\ University of Minnesota, Minneapolis, USA
}

\begin{abstract}
In this age, the challenges of urbanization, industrialization, globalization, and mechanization have been eroding the stability of communities. Additionally, every existence, including humans, suffers from nature's calamities and innate evolutionary changes - physically, mentally, and spiritually. India's cultural tradition, being one of the oldest, has provided diverse worldviews, philosophies, and practices for peaceful-coexistence. Quite often, the multi-faceted tradition has used different methods of syncretism relevant to the socio-cultural conditions of the time. Ideologically correct, "perfect" peace is unattainable. However, it seems necessary to examine the core philosophical principles and practices India used to create unity in diversity, between people of diverse races, genders, and ethnicities. The paper briefly examines the nature of India's cultural tradition in terms of its spirituality or philosophy of religion and its application to social constructs. Secondarily, the paper suggests consideration of the use of India's spirituality based on ethics for peaceful living in the context of diversity of life.
\end{abstract}

Keywords: diversity, ethnicity, ethics, peace, connectivity, interdependence, spiritual

\section{Introduction}

The world faces conflicts, violence, and wars in today's world of globalization and due to diversity of peoples, regarding race, gender, age, class, birth-place, ethnicity, religion, and worldviews. In addition to suffering resulting from conflicts and violence arising from the issues of dominance and subservience, we have to deal with evolutionary changes. Moreover, like many revolutions, scientific revolution has laid the foundations for a new and cruel authority, that of science itself. Science has become an ideological justification both for conserving and changing the social order. Men have used scientific discoveries to support their power over women, and Europeans asserted on scientific grounds their superiorities over the world's other peoples (Burns, 2001, p. xiii). These potentials of science were hardly fully developed in the scientific revolution itself - the dominant set of intellectual categories for analyzing was still religious at the close of the seventeenth century - but the seeds were there (Burns, 2001, p. xiii).

In the 21 st century, new revolutions in technology have hit the globe and created chaotic conditions in every region of the world. History has shown that India and its cultural tradition survived in the face of constant invasions by people or machines, natural disasters, drought, famine, and tsunamis. India will survive through technological advances and global conflicts. The reason for India's resilient sustenance over a period of thousands of years is rooted in her spirituality that is accommodative and synthetic, which accepts people of diverse races, gender and ethnicities. Indian cultural tradition is marked by inclusive spirituality, ethnicities, and adherence to ethics of non-aggression, peaceful co-existence, and concerns for humanity. Diverse social phenomena and customs are relevant to philosophies of India's religions: Hinduism, Buddhism, Jainism,

Indira Y. Junghare, Ph.D., Professor \& Research Scholar, University of Minnesota. 
Sikhism, and Sufism. India's philosophies and religions are variants of the Hindu philosophy, and due to cultural contacts over many centuries have formed "one" single all-inclusive, interdependent and interconnected tradition. The paper examines the spirituality aspect of the Hindu tradition, its social reality and its implications for justice and peace.

\section{India's Philosophical Tradition: Historical Development}

The Indian socio-linguistic-cultural tradition, being older than Greco-Roman cultures (going back to 2000 B.C.) dealt with problems of diverse invasions from the West, nearly five hundred years of Islamic rule, and one hundred fifty years of British rule, that made it more accepting and accommodating. It borrowed new ideas, new philosophies, both secular and religious, making the tradition "all-inclusive" of the one underlying Absolute "the Almighty" with its diverse surface forms as perceived by diverse individuals and diverse cultures. Just as Sanskrit served as the foundational language for the discipline of Indo-European linguistics, it became the sister of Latin and Greek, serving as the language of Indo-European religions in general and in particular Indian religions: Hinduism, Buddhism, and Jainism. The historical development of Indian languages from Sanskrit to Prakrit and Pali and to Modern Indo-Aryan languages gave rise to diverse heterodox philosophies of Buddhism and Jainism: The language Pali produced the philosophy of Buddhism, while Prakrit provided the worldview of Jainism. After Buddha's and Mahavira's passing, their followers organized their philosophies into the texts of Buddhism and Jainism, respectively (Robinson \& Johnson, 1997, p. 51).

\section{Theoretical Background}

Philosophies of life have always existed. In fact, such philosophies are fundamental to the human mind. Thought precedes its expression. In physical sciences, theories in the form of hypotheses are tested through experiments. In social sciences, theories are built through quantitative analyses of the data on socio-cultural aspects of the society being studied. Both sciences use the dialectical process as triad: thesis, antithesis, and synthesis as pointed out by German philosopher Fichte Johan Gottlieb (1762-1814) (MacGregor, 1989, p. 184). All legitimate generalizations and universals result from deductive reasoning, starting with perception of an individual or a particular phenomenon. Reasoning involves acquisition of knowledge (through senses), processing of thinking, comparison with others' knowledge, and formation of concepts and generalizations.

Philosophers use the same reasoning process. India's philosophies have focused on metaphysics, ontology, and the search for universal truth (Puligandla, 1975, p. 160). Since ontology cannot be separated from epistemology, Indian philosophers used additional sources for obtaining knowledge - the mind's deeper perception (intuition), comparison and testimony (words of the authority), for these philosophers were primarily concerned with eliminating human suffering caused by biological evolution in time and space. Some Indian philosophies became idealistic, focusing on the universal phenomena, including the concept of God as creator, mover, or sustainer. Some philosophies dealt with mind and matter, while some combined the study of: mind, matter, and deep mind (conscience-soul-spirit). In general, both Greek and Indian philosophers of earlier centuries were scientists, metaphysicians, mystics, and healers.

We are moving towards one world and towards a world philosophy (Vyas, 1982, p. xi). Necessity of a world philosophy is felt much more in the present situation. Therefore, some of the Indian philosophical concepts are worth studying due to their relatively successful applicability in peace making, peace keeping and everyday functioning. What the world needs today is not a theoretical philosophy but a philosophy with a 
pragmatic approach to life.

\section{The Concept of Religion in Indian Culture}

The concept of "religion" as applied to Western religions (Christianity, Islam, and Judaism) is absent in India's philosophical tradition. In fact, "religion" is not an Indian word. There are almost no Sanskrit or Pali equivalents of "religion". The word "dharma" in modern Indian languages is sometimes used in the sense of religion. Matilal (1982, p. 153) states that dharma as it is understood in Dharmasastras does not carry this sense (quote from Kane 1930-1962). Fortunately, in Indian religions, the belief in the existence of a Supreme Being is not as central as it is in Christianity or Islam. Therefore, theology does not have to be an all-pervasive concern in the study of religion. As philosopher Matilal (1982, p. 171) states, "The study of religions can be a humanistic study - a study that helps us so much in understanding art, poetry, literature, mythology, history, and architecture because in each, religion has found expression. So, the study of Indian religion should include not only Hinduism, Buddhism, Jainism, but also Islam and Christianity". The study of Indian tradition in this article not only follows Professor Matilal's philosophical model, but also uses his broader analytical perception of religion and philosophy's reflection in liberal arts as human's extra-ordinary, almost divine, creation. His reasoning is similar to: If God created man in his mirror image, then man's creation of arts is his indirect creation through divine inspiration.

\section{Methodological Approach}

The approach to the study of Indian cultural tradition is interdisciplinary, philosophical, socio-linguistic, and semantic. Indian tradition is philosophically idealistic, culturally realistic, and in compliance with its socio-cultural ethics. This tradition defines God as an absolute power, limitless, non-definable, and non-describable. It is realistic in the sense that no one has proven the existence of the God. That does not mean $\mathrm{He} / \mathrm{She} / \mathrm{It}$ does not exist. It is wrong to make an absolute statement about a hypothetical entity. The Indian cultural tradition is pragmatic in permitting people to see God according to their own perceptions and beliefs, while not excluding or persecuting those who hold diverse views. The Indian cultural tradition reflects the synthesis of religions and philosophies, idealism and relativism, individualism and collectivism, monism (Absolute God), dualism (two creative principles — masculine \& feminine), and non-dualism (unity of two - the Absolute and the Relative world). This paper discusses some of Indian culture's humanistic aspects: diversity, spirituality, inter-connectedness, ethics of identity, dignity, rights, and peaceful coexistence and examines whether these aspects relate to modern Indian culture.

\section{The Concept of "Culture"}

Culture is a composite category that includes language, nationality, and worldview.

Culture is the sum total of ways of living built up by a group of human beings, which is transmitted from one generation to another. (The Macquarie Encyclopedic Dictionary)

Culture is that complex whole which includes knowledge, belief, art, morals, law, customs and other capabilities or habits acquired by members of society. (O’Sullivan, 2004, p. 2)

It is the sum total and the organization or arrangement of the group's ways of thinking, feeling, and acting... (O'Sullivan, 2004, p. 2) 
The first two definitions of culture focus on the external or societal aspect of a group/tribe, whereas, the third focuses on the personal or psychological aspect of a being, not just a man but all types of men, rich, poor, educated, illiterate, belonging to upper castes and lower castes, and also gay, bisexual, and transsexual beings, and all types of women - old, young, married, non-married, widows, lesbian, and disabled. India's culture is representative of all religious and secular, divine and mundane aspects of life. Therefore, it is necessary to see to what extent theories are materialized in practice.

\section{Evolutionary Development of the Hindu Tradition: Diversity}

The Hindu tradition has developed over a period of five thousand years and experienced many invasions. Every invasion has led to Hinduism adapting and assimilating others' ideas, concepts, languages, and values. Constant negotiation of ideas resulted in synthesizing new philosophies and customs. The evolutionary development of the tradition over a long period of centuries, and its flexibility in acculturation promoted its breadth and depth.

After three months of exploration in India, Mark Twain wrote (Mutalik, 1978) in wonder:

Nothing has been left undone, either by man or nature, to make India the most extraordinary country that the sun visits on his round. Nothing seems to have been forgotten, nothing overlooked.

India is the cradle of human race, the birthplace of human speech, the mother of history, the grandmother of legend, and the great grandmother of tradition. Our most valuable and most astrictive materials in the history of man are treasured up in India only!

--Mark Twain

\section{Literary Tradition: Concepts of Duty, Ethics, and Peace}

During her cultural development, India has composed various texts: religious, philosophical, literary, mythical, devotional, popular, folkloric, and regional, making Indian tradition perhaps richest in cultural diversity. The most influential scriptures are the epics, the Ramayana, the Mahabharata, and the Puranas, the ancient mythologies. The epic Mahabharata contains the Bhagavad-Gita, "The Song of the Lord", which is comprised of seven hundred verses containing Krishna's teaching to the conflicted prince Arjuna, who is overcome with sorrow, concern, and confusion. This text serves as the primary scripture in modern Hinduism. The message from the teacher Krishna is that the diversity of phenomena in the universe are manifestations of the same reality, the unifying factor known as Brahman (life's essence). The text teaches methods necessary to overcome limitations of egotistical thinking and how to set oneself free of the burdens of the falsities of the external world (Satchidananda, 1988). Duty is central to maintaining universal harmony, as noted in the aphorism: "Do your duty with no expectations for fruits".

Mahatma Gandhi used the Bhagavad-Gita and its message as moral foundation for his political non-violence movement, providing a technique called satyagraha "insistence on truth" through peaceful means for social and political change (Kripalani, 1988). Gandhi was a political activist and practical philosopher. He was not a theorist. Gandhi's important contribution lies in the development of the concept of "dignity of labor", to raise the value of common people, inclusive of people of color, women, young and old. Gandhi's philosophy is "a system of ethics, a way of life, a metaphysical formula, or a religion complete with ritual and hagiology" (Kripalani, 1988, p. 8).

Gandhi's peace movement was reflective of two types of peace, inner and outer, and related to two types 
of force. It meant the exercise of physical or intangible power or influence to effect change. Violence is the willful application of force in such a way that it is intentionally injurious to the person or group against whom it is applied. Injury is understood to include psychological as well as physical harm (Bondurant, 1988, p. 8). Coercion has been defined as "the use of either physical or intangible force to compel action contrary to the will or reasoned judgment of the individual or group subjected to such force" (Bondurant, 1988, p. 9). The original concept of truth as the absolute truth or God, known to the Western world was made into: God is truth and who knows it better than the knower? In Western theology, "truth is God" which means only God exists. Gandhi defined: "Truth is God". Most of the Western socio-political-moral concepts have been brought down to the level of relative reality, ethicality, and humanity.

Essentially, Gandhi used the moral philosophy found in the Bhagavad-Gita as a means to effect socio-political change, in contrast to Western philosophy, which has been content with the treatment of means as abstract method. The Gandhian way, and by extension the Indian way, values reality, allows flexibility, promotes diversity, and creatively helps people attain internal and external peace.

\section{Essential Nature of Hinduism: Religious/Idealistic Spirituality}

On a popular cultural level, Hindu spirituality is anthropomorphic and recognizes divine being in human form and human attributes in divine form (Babb, 1975). On the philosophical level, Hinduism has created the concept of "all-inclusive", "non-definable", "non-comprehensible", "non-describable", and "limitless" Absolute/Ultimate Reality (Brahman), which is left to an individual or his society to define or perceive (Puligandla, 1975). This abstract concept is realized in two forms depending on the situation: Nirguna Brahman "Brahman without qualifications", and Saguna Brahman "Brahman with qualifications".

On the philosophical and psychological level, this concept of Brahman creates unity among diverse perceptions of God, the creator of the cosmos that includes all beings and all things (Junghare, 2011). On the cultural and societal level, it permits flexibility and tolerance for diverse perceptions and interpretations of God as the Lord of the Universe. This unifying concept has been expressed by ancient scholars: "God is one, but called by different names" (Junghare, 2011). The adaptation of this concept allows Hindus to worship Christ or Buddha or any god. The Brahman with attributes can then be realized as a female, bisexual, transsexual, animal, plant, or substantive element such as earth, water, fire, etc. This concept further teaches compassion and non-violence and allows individuals the freedom to practice in a multitude of ways.

The second divinity-related concept that has caused negative perceptions of Hinduism is that of "worship". Hindus are criticized for their worship of not only people but also of natural objects - the sun, animals such as cows, bulls, and plants. Some of the criticism comes from misunderstanding and inaccurate translations of Sanskrit philosophy, while some are due to evolutionary changes which took place in the process of language development from Sanskrit to Prakrit, and from middle Indo-Aryan languages to modern Indian languages; for example, the word "puj" which meant "to honor" has been mistranslated as "to worship". Hindus do not worship people, animals, and plants as gods, but honor them for their utility aspect and as part of Nature.

On a personal level, philosophical utilitarian ethics combined with the concept of divinity leads to the concept of "dignity and right of existence" (Junghare, 2014). In other words, every being, whether human, animal or plant, has the right to exist for it is a divine creation, the purpose of which is to contribute to all-inclusive existence. Thus, the freedom of worship/honor and ethics of dignity and respect allow for peaceful co-existence at all levels of the cosmos. 


\section{Equitability and Ethics}

The word equitable means "fair, just and right". The meaning becomes clear if added "in his/her own stance". This extended definition allows all people freedom of choice in profession, faith, dress, and custom. The basic concept of equitability has been in existence in India's oldest literary compositions, known as the Vedas "the knowledge books", composed around 1500 B.C. The Vedas and Upanishads promoted philosophical relativism and ethical humanism and allowed everyone freedom for rightful living. These texts tell us that all knowledge, experiences and needs are relative to individuals and cultures. All depends on one's stance (MacGregor, 1989). Different things are important to different people translates into ethical relativism.

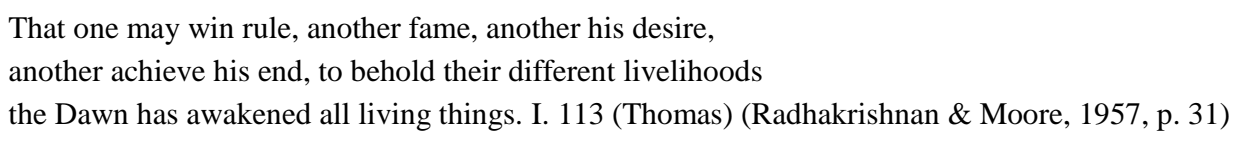

The goals of life in Hinduism are to attain infinite knowledge, infinite awareness, and infinite bliss (Smith, 1991, pp. 20-21). The paths to attain these goals are: knowledge, action, devotion, and freedom from suffering. Hinduism takes into consideration the evolutionary nature of life, i.e., stages of life and their relationship to successful accomplishment of goals. For example, when young, one should study; and when of marriageable age, one should seek employment in order to support a family.

\section{Infinite Diversity: Infinite Spirituality}

The chief mark of Indian tradition is its concentration upon the spiritual. Both in life and in philosophy the spiritual motive is dominant. Individual philosophy conceives man to be spiritual in nature and relates him to a universe, which is also spiritual in essential character (Radhakrishnan \& Moore, 1957, p. xxxiii).

Scientifically speaking, it may seem that life is only mind and matter, or united embodied mind, or molecules. What about human spirit? The original meaning of "spirit" is spiritus meaning "breath". The Latin word anima, Greek word psyche, and Sanskrit word atman have all referred to the inner mind or soul. Capra (2002, p. 68) justifies this philosophical concept as a perfect metaphor for the network of metabolic processes that is the defining characteristic of all living systems. Spirit - the breath of life-is common to all living beings. To quote Capra (2002):

Spiritual experience is an experience of aliveness of mind and body as a unity.

This experience of unity transcends not only the separation of mind and body,

but also the separation of self and world. (p. 68)

Thus, Indian tradition recognizes the polarity and diversity of concepts and phenomena and unites them in a spirit of non-duality. This scientific observation was the central insight in the philosophical texts known as the Upanishads: the identity of Atman and Brahman. This theme of spiritual unity became the philosophical system of Vedanta by Shankara during the eighth century (Puligandla, 1975, p. 207). This philosophical system states that the totality of existence is in God but not equal to God. God is not exhausted by the universe but is greater than it. The concept of spirituality created unity between God, Man and World. Philosophers from the beginning of Indian civilization revealed a profound religious consciousness that permitted acceptance and growth of the diversity of life. 


\section{Sacred Nature of Life and Interconnectedness}

Indian tradition's spirituality influenced the common folks of India. Perhaps the composers of the Upanishads were common folks expressing awe and wonder about the universe and its creation. The philosophical system of Vedanta became formalized during eighth and twelfth century in three forms: Nondualism (Unity of God and man) by Shankara, Qualified Nondualism (God with special attributes) by Ramanuja, and Dualism (Supreme God vs. imperfect human) by Madhva (Puligandla, 1975, pp. 191-241). Of the three types of philosophies, it is the first one that helped sustain diversity of life, as it was inclusive of all diverse beings with "one" God.

The second concept of creating unity in the multi-faced Indian tradition was the concept of sacredness. The philosophy of Hinduism considers the whole cosmos sacred and ruled by the divine order. Every part of the cosmos, people of all shapes, sizes and colors, animals of all kinds, plants and elemental life such as mountains, rivers, the sun and moon received the status of sacredness. Recognition of the purpose and function of every part of life guided by the Cosmic Law of Nature and contributing to the totality of existence makes everyone and everything worthy of respect and veneration. No wonder then, this concept of veneration is reflected in the "worship" of the sacred river Ganges. This is not to say that people truly think that Ganges is a goddess as such. The word in Sanskrit for honoring the sacred is puj "honor". People have been honoring the Ganges and thinking that she aids them through the power of their own sacredness and that of the Ganges. This aspect of the ethics of utility has been recently recognized by the government of India by giving the Ganga [Ganges] river its right ${ }^{1}$ (like a person) to exist in efforts of protecting and restoring the eco-system as her water has been overused, bringing her existence to extinction ${ }^{2}$. This is similar to the animal rights movement. In modern times people make laws. In ancient times, philosophers envisioned life's governing principles for collective health, and commoners followed the principles out of respect for the knowledge-producing authority. Relationships between learned and common people consisted of mutual and collective guardianship rather than dominance and subservience.

The philosophy just described gives rise to the concept of dignity of every form of existence (not just human existence), through recognition of innate sacredness and divinity connecting all elements of the universe. Hindus believe separating objects and events is an illusion of reality (Capra, 2000). This illusion arises from ignorance (avidya). An action cannot be without an actor; mind cannot be without body. Body holds mind and they spiritualize (energize) each other. Space and all things in it are controlled and governed by the laws of nature (Ridley, 2010). Unity and inter-connectedness mark the nature of existence. Plants and animals have equal worth to humans. They develop, grow, and display similar forms and functions. All forms possess consciousness leading to compassion, non-violence, and respect for all living and non-living things. Respect is the underlying principle for balanced functioning of the cosmos.

The concept of sacredness combined with interconnectedness of all beings through dignity of existence is the essence of Hindu spirituality on all levels: personal, societal, global, and universal. To put it simply, every form of life deserves to exist and has a right to exist with dignity (Junghare, 2014).

\footnotetext{
${ }^{1}$ Rights for Ganga (c) 2012 www.gangaaction.org; accessed on April 7, 2017.

2 https://www.theguardian.com/world/2017/mar/21/ganges-and-yamuna-rivers-granted-same-legal-rights-as-human-beings; accessed on April 7, 2017.
} 


\section{Reflection of Philosophy in Culture}

\section{Gender, Sexuality and Ethnicity in India}

Women. Historically, in ancient India, women enjoyed equality with men, particularly during the time of the Vedas ${ }^{3}$. In the traditional Vedic wedding ceremony the ritual of Saptapadi, where the bride and bridegroom take seven steps together around the nuptial fire (Agni) and make seven wedding vows to each other, is the most important ritual in the ceremony.

According to the Vedic writings, the words "perfect halves to make a perfect whole" concerning the relationship between husband and wife, provide the same religious rights and privileges to women as to men. Neither woman, nor man is superior. Both are perfect halves to make a perfect whole. This teaching, however, changed over time. After the publication of the Manusmriti "The Laws of Manu", women began to lose their independence:

Her father protects (her) in childhood, her husband protects (her) in youth, and her sons protect (her) in old age; a woman is never fit for independence. (Manusmriti 9.3; Bühler \& Muller, 1886)

This translation is subject to different interpretations. For one thing, the translation is in English, and the translator is a Western man. Sanskrit words do not necessarily translate well in English. Moreover, the translation seems to reflect a male bias. It is unbelievable that the philosophy which held all people equitable, as explained above, could suggest such a non-dignifying treatment of women, especially in the context of respect for all life, and especially for the writers of the knowledge texts. The proper meaning implies that women are physically a weaker sex and are likely to be victimized at all times. Is it not the case even today? Women have not been free from domestic and public abuse in every culture of the world. The bullying of women by educated elites, especially in power, is an everlasting truth.

The assumption of the inability of women to be independent stems undoubtedly from the fear of the strength and power, Shakti, they possess when unburdened by marriage and family duties. Further, single women are also seen as a threat to society for they possess the power to govern themselves. Men found such independence unbearable and so women's position in society was lowered and kept as subservient ${ }^{4}$. Sadly, this has been one of the characteristics of a patriarchal society, and Indian society is no exception. During the Islamic rule of five hundred years, the Muslim influence on India caused considerable deterioration in the status of women. They were deprived of their rights of equality with men (Singh, 2000) ${ }^{5}$.

Several social reformers, just to name a few, Raja Ram Mohan Roy, Swami Vivekananda, Jawaharlal Nehru and Mahatma Gandhi contributed to the revival of Indian women's lost status. Dhondo Keshav Karve from the state of Maharashtra was one of the pioneers of promoting women's education. Indian women's participation in the political processes, especially Gandhi's "Free India" movement, made them politically competent. Indira Gandhi became the first woman prime minister in the world. Since India's independence women have earned the same rights offered to men. Laws related to women's issues can confirm Indian women's political progress: (1) The Sati Prevention Act, 1987; (2) Prohibition of Child Marriage Act, 2007; (3) Protection of Women from

\footnotetext{
3 V. Jayaram. "Hinduism and Women". Hindu Website. Hinduismwebsite.com, n.d. Web. 19 Apr 2010. http://www.hinduwebsite.com/hinduism/h_women.asp.

4 "Women in Hindu Religious Thought". tripod.lycos.com. N.p., $\quad$ n.d. $\quad$ Web. $21 \quad$ Apr 2010. http://sanatanadharma.tripod.com/women_in_hinduism.htm.

${ }^{5}$ Rekha Singh https://www.bu.edu/wcp/Papers/Huma/HumaSing.htm. Retrieved on April 19, 2017.
} 
Domestic Violence Act, 2005; and (4) Compulsory Registration of Marriage Act, 2006. In addition, acts specifically related to employment are: (1) Employment Insurance Act, 1948; (2) The Maternity Benefit Act, 1961; and (3) The Equal Remuneration Act, 1976 (Singh, 2017). The above legislation and other emancipating actions of the social reformers have no doubt raised the status of Indian women. The Hindu Code Bill has given the daughter and the son equal share of the property. The Marriage Act no longer regards woman as the property of man. Passing of law is one thing and its absorption in the collective thinking of society is quite a different matter. In order to prove themselves equal to the dignity and status given to them in the Indian Constitution women have to shake off shackles of slavery and other societal oppressive acts (Mandal, 2014). ${ }^{6}$

In conclusion, the findings above prove that Indian women, relatively speaking, have done better after India's freedom. The roots for progress lie in the spirituality of the social reformers who stood on the shoulders of their ancestors and used their knowledge and wisdom in understanding and removal of human suffering, including that of women, to the best of their ability.

Sexuality in Hindu Culture. Often people confuse gender and sexuality. The sex of an individual is often determined biologically, whereas gender refers to societal roles based on the sex of the person. Also, sexual behavior should not be confused with sexuality. India, by and large, remains a traditional socio-centric society rapidly moving to an ego-centric society due to urbanization, industrialization under the overall impact of globalization (Kalra, Gupta, \& Bhugra, 2010, pp. 264-8).

Sexuality in Hindu culture is often a widely misunderstood and misrepresented concept when viewed by many in the Western world (Menon, Hartsock, \& Johnson, 2010). Many conflicting ideas arise, such as the renunciation of sexual activity by ascetics and the embrace of sexuality by the Tantric tradition. Often a confusing subject in any culture, Hinduism embraces contradiction and chaos and this confusion extends into the realm of sexuality. Generally speaking, the two main views on sexuality can be split into two groups, the main way of thinking and the Tantric way of thinking.

In the main way of thinking, sexuality is approached in a way somewhat similar to Western thinking. Sexual activity outside of wedlock is traditionally not approved. The concept of purity-pollution has been prominent in ritualistic Hinduism. Sex is considered to be pollution rendering. This opinion is weighted more towards women than men because an impure woman is seen as corrupted and untouchable, whereas a man does not necessarily become marked as a woman would be by sexual activity. Philosophically, the renunciation of sexual activity is viewed as empowering. The concept of sexuality in Indian culture presents a paradoxical picture: it is feared on the one hand and respected on the other. As stated by Menon, Hartsock, and Johnson (2010) from Patheos (2010):

...in the Hindu tradition sexual activity is usually regarded as debilitating to men. Morris Carstairs (1956) cites a rustic aphorism that expresses succinctly a prevailing attitude about masculine sexuality: "it takes forty days, and forty drops of blood, to make one drop of semen". The converse of this principle is, of course, that sexual renunciation will lead to the acquisition of power... ${ }^{7}$

Third Gender: LGBT (Lesbian, Gay, Bisexual \& Transsexual). Although religion and spirituality played a role in shaping India's cultural traditions and customs, homosexuality has not been explicitly

\footnotetext{
${ }^{6}$ Puja Mandal http://www.yourarticlelibrary.com/essay/women-essay-on-the-position-of-women-in india/31314/; accessed on 12 April 2017.

"Hinduism Gender and Sexuality". Patheos. N.p., n.d. Web. $14 \quad$ April 2010. http://www.patheos.com/Library/Hinduism/Ethics-Morality-Community/Gender-and-Sexuality.html.
} 
mentioned in the religious texts. The earliest Indian text on human sexuality Kamasutra is believed to have been written by Vatsyayana during $400 \mathrm{BC}-200 \mathrm{AD}$. This text provides a guide to virtuous and gracious living in a discussion of aspects pertaining to pleasure of human life. Hindu culture recognizes homosexual/transsexual dimensions of human life, which can be seen in popular saying of the Vedas:

Vikriti Evam Prakriti "What seems unnatural is also natural”. (Rig Veda) (Griffith, 1926)

Yet another popular saying in Marathi, official language of the State of Maharashtra, is: "As many individuals, so many different bodies" (vyaktititkyaprakrti). The Indian subcontinent has addressed LGBT issues actively through diversity and sexuality.

As noted by Mark Twain, cited earlier, all people, regardless of their sexual orientation, were considered to be a valuable part of human race, a priceless part of the cosmos. ${ }^{8}$ Historical evidence indicates that homosexuality has been prevalent across the Indian subcontinent throughout history, and that homosexuals were not necessarily considered inferior in any way until about the eighteenth century (Nanda, 1998). After Puranic and Tantric religion (300-700 A.D.), the God Shiva began to be depicted as Ardhanari-Nateshvara "the Androgen Dancing Lord". Also, temples of Khajuraho in Madhya Pradesh, India, built around 1100 A.D., depict homosexuality. In Gujarat, a temple is specifically dedicated to the goddess "Bahuchara Mata" who serves as the goddess for the "third gender" which includes different forms of sexuality: lesbian, gay, bisexual, and transsexual.

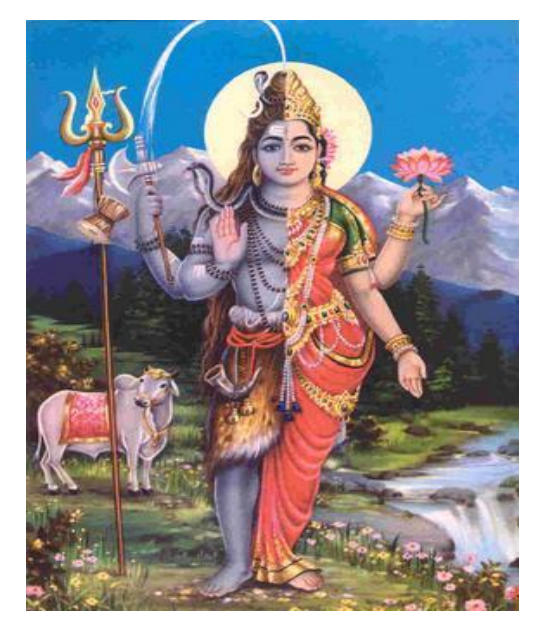

Figure 1. Androgen Shiva. Sources: calendars.

\footnotetext{
${ }^{8}$ Magazine Web Edition, April 1996; Mark Twain's Little Known Travels in India; retrieved on December 24, 2016.
} 


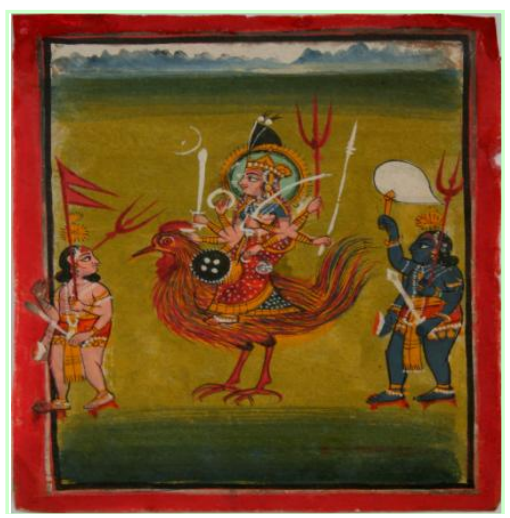

Figure 2. Bahuchara Mata, Patroness of Hijras (LGBT). Sources: calendars.

India, along with Pakistan, Nepal, and Bangladesh, has legally recognized transgender people as third gender. ${ }^{9}$ The Supreme Court in National Legal Services Authority vs. Union of India and other cases decided on 15 April 2014, that the category hijra designated "as neither man nor woman", and transgender constitute a third gender in law.

Hijras of India have been religiously respected and honored. They form a community who sing and perform at weddings. They have been protected as per the law despite social ostracism. However, the transgender community has experienced physical, psychological and sexual violence from the Indian police. To conclude, Indian tradition did not have problems with the diversity of sexes. If Shiva could be androgynous, then everybody could be whoever he or she wanted to be. This ancient pattern has been carried out in modern India. These patterns show that Indian civilization has never abandoned ancestral teaching. Rather, diverse principles have been adapted when needed. The tradition's flexibility helped sustain diversity.

\section{Ethnicity in Indian Culture}

The concept of ethnicity differs from that of religion. What is ethnicity? The concept refers to cultural factors, including nationality, regional culture, ancestry, and language (Fought, 2006). Diversity may well be the fundamental and quintessential aspect of Hinduism. Applied as an ethnic label, "Hindu" has, in the past, been used to mean essentially all Hindu populations in South Asia. Indians, Pakistanis, Bangladeshis, Sri Lankans, and others too, have all been categorized as Hindu despite a wealth of various religious traditions being represented among these countries: not only Hinduism, but also Buddhism, Sikhism, Jainism, Islam, Christianity, and Zoroastrianism. As a religious label, "Hindu" covers numerous ethnic populations and crosses countless borders as globalization encourages the spread of culture and people (Menon, Hartsock, \& Johnson, 2010). The term "Hindu" originated during the Mogul rule, as a mispronunciation of the word Sindhu river (by Persians), meaning "people living on the banks of the Sindhu river". The British initially referred to the Mogul's Hindustan as "Greater India" and only later as India. Here the term ethnicity is used for the culture of people in the region of South Asia, inclusive of their languages, heritage, religion and customs. People conforming to some or all of those practices are considered to be members of an ethnic group.

India's socio-cultural system, to a prominent degree, is born from the spread of culture and peoples. The nomadic Indo-Europeans and Indo-Iranians encountered the established Indus civilization, which had thrived on the Indian subcontinent, and the exchange of these contrasting cultures (the agrarian and stable Indus, and

\footnotetext{
${ }^{9}$ The Guardian, 15 April 2014.
} 
the militarized and mobile Indo-Europeans) created the earliest forms of what would now be recognized as the religious and socio-cultural system that is Hinduism (Hopkins, 1971).

The relative isolation of the region meant that the Aryans encountered little culture beyond that of the Indus people, so the two interacted on a not-necessarily equal ground, but certainly a contained and stable ground. What developed from these conditions was a culture that was rooted firmly on European ideas but flavored with local, non-European practices. This rather accommodating situation established a precedent for the future of Hinduism. Embedded in its religious observances, and at the heart of its socio-cultural ideals, are inclusive, communal, cooperative, and peaceful tendencies (Menon, Hartsock, \& Johnson, 2010).

The state of Hinduism today is still notably diverse. Although Hindu traditions and philosophies are particularly linked to India, Hinduism still boasts astonishing ethnic diversity among its adherents. Hindu traditions have been spread throughout South Asia, influencing Thailand, Cambodia, and Burma, to name several that might highlight the obvious ethnic diversity within Hinduism. Further ethnic diversity is apparent and is distinguished through ethno-linguistic categories. There are four prominent socio-linguistic categories on the Indian Subcontinent: Indo-Aryan, Dravidian, Austro-Asiatic, and Sino-Tibetan. Within each of these classifications there exist a number of more distinct ethno-linguistic populations, speaking different languages and dialects.

The Indo-Aryan group, notably prominent in Northern India (but also extending beyond the political borders of India), includes Hindi, Hindustani, Gujarati, Bengali, Oriya, Assamese, Konkani, Marathi, Punjabi, Sindhi, Magadhi, and Maithili as some of the ethno-linguistic populations that have sizeable groups of religious Hindus.

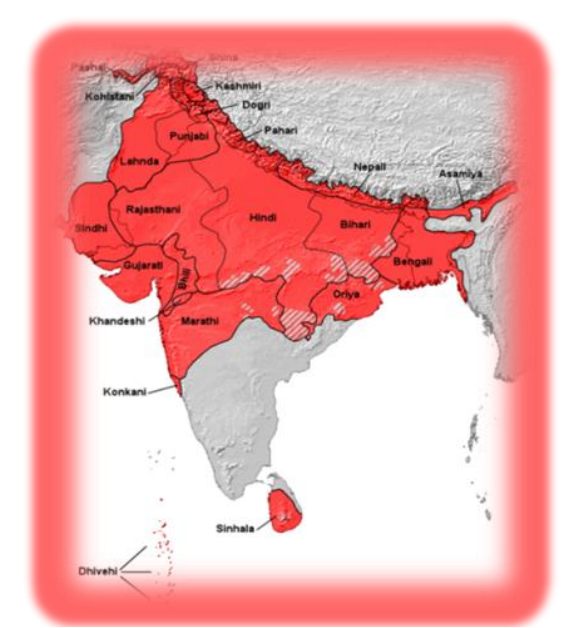

Figure 3: Aryan Languages (Menon, Hartsock, \& Johnson, 2010). 


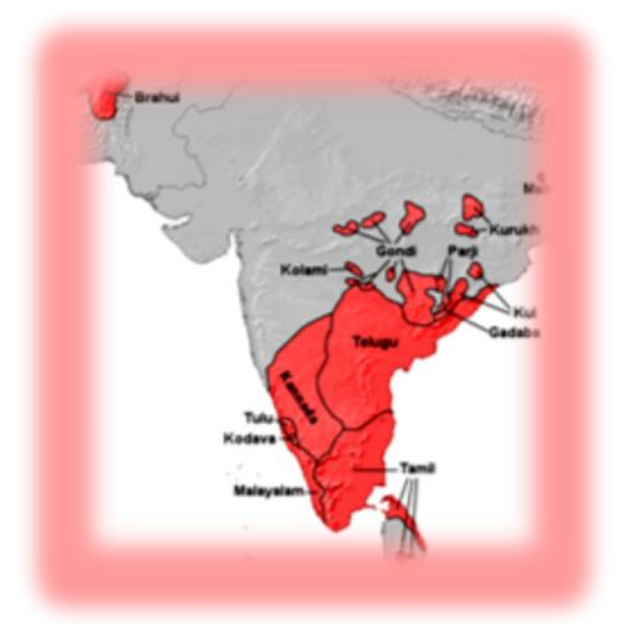

Figure 4. Dravidian Languages (Menon, Hartsock, \& Johnson, 2010).

The Dravidian group (not limited to, but prominent in, Southern India) includes Gondi, Kannada, Tulu, Tamil, Telugu and Malayalam among its religious Hindus. The Austro-Asiatic group includes the Khasi, which has a population of religious Hindus, as well as the Munda, a people indigenous to the Indian subcontinent, although these peoples are not adherents of Hindu socio-cultural or religious ideas. The Sino-Tibetan group includes the Gurung, Magar, and Tripuri peoples as those that have Hindu adherents. There are, however, also several ethno-linguistic populations among the Sino-Tibetan group that have a small minority of Hindus, or whose religious practices have been influenced by Hinduism but remain distinct from it. These include the Nishi, Thakali, Newar, and Chepang (Menon, Hartsock, \& Johnson, 2010).

Hinduism holds ethnicity to be of little import, compared to some other religious traditions. Furthermore, Hinduism has little in the way of formalized practices for conversion and does not pursue converts in an imperative way as does Christianity or other Abrahamic religions. This non-aggressive approach to the continuation of Hindu ideas, along with the inherent flexibility and knack for cultural appropriation cultivated from the very start, might be the reason that Hinduism has continued to thrive despite significant changes in global cultures. The ability to adapt is indicative of the distinctive aspects of Hindu ideals. Since Hinduism is not religiously dogmatic and, in general, is inclusive, communal, peaceful, and cooperative, it is attractive as a source of socio-cultural ideals. By allowing access to so many and accommodating individual needs, Hinduism not only is able to effectively sustain its existence, but also allows itself to be enriched by the diversity, which it inherently embraces.

\section{Biological Spirituality}

\section{Nature in Hinduism}

As scientific and spiritual fields continue to develop broader understandings of our existence, one thread continues to connect humanity: the appreciation of natural biodiversity stemming from evolution (Wilson, 1999). As over-consumption runs rampant in modern society, it is important to consider the environmental conservationist argument as stated by Wilson (2006):

Life on this planet can stand no more plundering. Quite apart from obedience to the universal moral imperative of saving the Creation, based upon religion and science alike, conserving biodiversity is the best economic deal humanity has ever had placed before it since the invention of agriculture. (p. 99) 
The easiest area to reconcile our intuitive spirituality and logical scientific minds is the natural human connection to our planet's wide variety of life forms (Elgin, 2009). This divine diversity is considered "the creation" by several religions including Hinduism, but also as "nature" by science. In appealing to the inner connection with the natural world, the biological theory of evolution can coexist peacefully with the world's religions.

In fact, Hinduism has explored the laws of physics and natural sciences and made them part of its metaphysics (Junghare, 2015). Hindu philosophy connected all types of existences-all statured humans, animals, plants and substantive beings of diverse forms, shapes, colors and content, making them into a web like existence.

\section{Hinduism and World Peace}

World history has shown that religious faith has been a very divisive force from primitive days of our civilization. It is doubtful whether any religion, including Hinduism, can bring unity and peace. In linguistics, unless you are a native speaker of a particular language, you cannot be a member of that language representative culture. The same idea is expanded to imply that anybody with a different faith, different set of beliefs, customs, habits, must be a stranger and therefore an enemy. Therefore, basically, there is very little difference between language-culture group fights and international wars. Even today "religion" is a contributing factor to the crises in the Middle East and in the Indian subcontinent. So should the whole world convert to one religion? That still leaves out other conflict-creating factors: diversity of gender, race, age, ethnicity and place of origin of birth. The only option remaining is to argue for the conversion or transformation of the notion of religion (Matilal, 1982, p. 169).

According to Matilal (1982, p. 169), an individual is born as animal, and it is only our humanistic education that helps him/her to grow up to be a human being. Our society's education is supposed to be a humanizing process so that the child can grow up to be a civilized human. Therefore, religion should teach us to regard nobody as sub-human because he/she talks a different language, looks different, and behaves differently.

\section{Findings}

Analysis of India's cultural spirituality, ancient and modern, tells us that it is rich in diversity: of people, languages, cultures, philosophies, and religions. It is not simply Hindu spirituality of diverse designs, methods, approaches, and manners, but a political reality. Her people are bound in their relationship - not simply as brothers and sisters, but also as belonging to the infinite true spirit. The concepts of race, religion, ethnicity (language, and customs), gender, and sexuality in Hindu culture are societal and biological constructs of external identities, which are connected through the thread of sacredness. They represent the idea of unity in diversity. India's cultural diversity receives support from its solid philosophical and literary foundation, as it is all-inclusive, communal, cooperative and inviting.

\section{Implications}

The cultural tradition of India has often relied upon and drawn from India's secular and religious philosophies, both concerned with the welfare of humanity. Philosophy of the tradition, though distinct from Western theology, is complementary to Western philosophy and has the potential of serving a large part of humanity. Some distinguishing features of the Hindu cultural tradition are: 
(1) It does not demand faith in a particular philosophy of a particular religion and can serve as a general basic philosophy for humanity.

(2) Its spirituality emphasizes the sacred nature of all life, which helps empower people to do the right thing.

(3) Understanding the concept of equitability of all life can help reduce tension and conflicts at all levels-personal and societal.

(4) Understanding of the concept of interconnectedness can bring people closer.

(5) Indian tradition is concerned with life's suffering and its removal. It teaches ethics of non-violence in thought, word and action. It can serve as a world philosophy.

(6) Most importantly, the non-dogmatic and spiritual nature of Indian tradition can help promote core values or ethics of dignity, respect, honor, non-aggression, and nonviolence.

\section{References}

Babb, L. A. (1975). The Divine Hierarchy. New York, NY: Columbia University Press.

Bondurant, J. V. (1988). Conquest of Violence: The Gandhian Philosophy of Conflict. Princeton, New Jersey: Princeton University Press.

Bühler, G. \& Muller, F. M. (1886). The Laws of Manu: The Sacred Books of the East. Oxford: Clarendon Press.

Burns, W. E. (2001). The Scientific Revolution: An Encyclopedia. Santa Barbara, California: ABC-CLIO.

Capra, F. (2000). The Tao of Physics. Boston: Shambhala.

Capra, F. (2002). The Hidden Connections. New York: Anchor Books.

Carstairs, G. M. (1956). Hinjra and Jiryan: Two Derivatives of Hindu Attitudes to Sexuality. British Journal of Medical Psychology, 29, 128-138.

Elgin, D. (2009). The Living Universe. San Francisco, California: Berrett-Koehler.

Fought, C. (2006). Language and Ethnicity. New York: Cambridge University Press.

Griffith, R. T. H. (1920-1926). The Hymns of the Rigveda (vols. 2). Benares: E. J. Lazarus \& Co.

Hopkins, T. J. (1971). The Hindu Religious Tradition. Belmont, CA: Wadsworth Publishing Company.

Junghare, I. (2011). The Unified Universe: The Theory of Brahman. International Journal of Diversity in Organizations, Communities \& Nations, 10(6), 15-28.

Junghare, I. (2014). Identity: Ethics of Dignity. Redefining Community in Intercultural Context, 3(1), 43-54.

Junghare, I. (2015). A Synthetic Socio-cultural System: Physics and Metaphysics. The International Journal of Religion and Spirituality in Society, 4(4), 15-26.

Kalra, G., Gupta, S., \& Bhugra, D. (2010). Sexual Variation in India: A View from the West. Indian Journal of Psychiatry, 52, 64-8.

Kane, P. V. (1930-1962). History of Dharmasastra. Poona: Bhandarkar Oriental Research Institute.

Kripalani, K. (1988). All Men Are Brothers. New York: Continuum.

MacGregor, G. (1989). Dictionary of Religion and Philosophy. New York: Paragon House.

Matilal, B. K. (1982). Logical and Ethical Issues of Religious Belief. Calcutta: University of Calcutta.

Menon, A., Hartsock, C., \& Johnson, R. (2010). Socio-cultural Hinduism: Race, Gender, Ethnicity and Sexuality. Working Papers on Hinduism, University of Minnesota, Minneapolis.

Mutalik, K. (1978). Mark Twain in India. Bombay, India: Noble Publishing House.

Nanda, S. (1998). Neither Man nor Woman: The Hijras of India (2nd ed.). Belmont, CA: Wadsworth Publishing Company.

O’Sullivan, K. (2004). Understanding Ways: Communicating Between Cultures. Alexandria, NSW: Hale and Iremonger.

Puligandla, R. (1975). Fundamentals of Indian Philosophy. New York: Abingdon Press.

Radhakrishnan, S., \& Moore, C. (1957). A Source Book in Indian Philosophy. Princeton, New Jersey: Princeton University Press.

Ridley, E. (2010). Hinduism: Quantum Physics and Hindu Metaphysics. Working Papers on Hinduism, University of Minnesota, Minneapolis.

Robinson, R. H., \& Johnson, W. L. (1997). The Buddhist Religion: A Historical Introduction. Belmont: Wadsworth Publishing Company. 
Satchidananda, S. S. (1988). The Living Gita: The Complete Bhagavad Gita. Yogaville, Virginia: Integral Publications. Smith, H. (1991). The World's Religions. San Francisco: Harper.

Thomas, E. J. (1923). Vedic Hymns: Wisdom of the East Series. London: John Murray.

Vyas, R. N. (1982). Nature of Indian Philosophy. New Delhi: Asian Publication Services.

Wilson, E. O. (1999). The Diversity of Life. New York: W. W. Norton \& Company.

Wilson, E. O. (2006). The Creation. New York: W. W. Norton \& Company. 